EPiC Series in Engineering
Volume 3, 2018, Pages 780-787
HIC 2018. 13th International
Conference on Hydroinformatics

\title{
Analysing the cascading effects on critical infrastructure in Torbay coastal/pluvial flooding with climate change
}

\author{
M. J. Gibson1, A. S. Chen1, M. Khoury1, L. S. Vamvakeridou-Lyroudia1, \\ D. Stewart2, M. Wood2, D. A. Savić1, S. Djordjević1 \\ ${ }^{1}$ University of Exeter, Harrison Building, North park Road, Exeter, EX4 4QF, UK. \\ ${ }^{2}$ Torbay Council, Town Hall, Torquay, TQ1 3DR, UK. \\ M.J.Gibson@Exeter.ac.uk
}

\begin{abstract}
Critical Infrastructures (CIs) are commonly designed, built and maintained based on rigorous standards in order to withstand the climate and weather-related pressures. However, shifts in climate characteristics may result in increases of the magnitude and frequency of potential risks, or expose specific CI to new or increased risks not previously considered. As vital components of the normal functioning of modern societies, their resilience encompasses the operational elements, their structural integrity and the capacity to maximize business output under climate stressors. In this work, we propose an integrated and participatory methodological approach to assess the risk and enhance the resilience of interconnected CIs to urban flooding under climate change. The proposed methodology has been applied to the Torbay case study in the EU-CIRCLE project that is also presented in the paper.
\end{abstract}

\section{Introduction}

Torbay, in the South West of England, is a coastal district, which is susceptible to flooding (Figure 1). Due to the steep hill leading down to coast it suffers from frequent pluvial (surface) flooding, but also from extreme storms causing the sea to overtop or breach the coastal defences. 


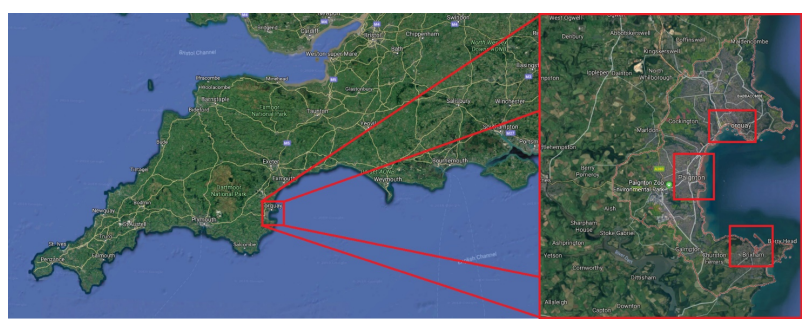

Figure 1: Location of the case study (left) in the South West of England, Torbay -Torquay, Paignton and Brixham (right)

In order to process several climate change scenarios for each of three target areas of Torquay, Paignton and Brixham, in a tractable amount of time for analysis, a fast modelling approach is needed. The CADDIES framework (Guidolin, et al., 2011) (Guidolin, et al., 2012) and associated caFlood(Pro) application, provides a fast means for 2D flood modelling and visualisation, which is utilised in the study. The caFlood application is based on Cellular Automata (CA) system, and uses the weighted model (Guidolin, et al., 2016) to distributed water flows between each cell of the computational grid.

For each of the three geographical locations considered, a high resolution 1 meter grid was applied to simulate flooding scenarios that include coastal, pluvial and combined conditions for the current and future climate change situations of 20,50 and 100 year ahead. At Paignton, a new sea wall has been proposed, and therefore an additional simulation that takes this into account has been performed.

\section{Setup}

\subsection{Terrain data/parameters}

The UK Environment Agency's (EA) Light Detection and Ranging (LiDAR) digital terrain model (DTM) data were used as the ground elevations for modelling. The LiDAR DTM was filtered from the digital surface model (DSM) (Priestnall, Jaafar, \& Duncan, 2000) using algorithms that remove surface features to build the so-called bare earth terrain. The process removes superfluous features of the data, which are temporary and therefore should not be modelled, such as vehicles, people, animals or trees. It also removes structures within terrain data which are critical to flow movements, e.g. buildings and curbs, and can even leave large indentation where buildings should be present.

In order to simulate the effects of building blockages on flow paths, while also allowing the flow to penetrate into buildings through doors and windows, the DSMs data are pre-processed, following the EA's approach for surface water mapping (UK, 2013), using the buildings and road layouts from the Ordnance Survey's Mastermap. All grid cells covered or touched by the road polygons are lowered by $12.5 \mathrm{~cm}$ from their existing terrain level to account for the true elevation of roads, while buildings are treated differently in order to produce a level surface for each buildings polygon. The highest elevation within each building polygon is located and all cells within or touched by the polygon are raised to this level plus a threshold of $15 \mathrm{~cm}$. This is designed to simulate the door step level of the building, after which flow will be able to enter the cells that represent buildings. However, without further parameter settings this would neglect the influences of buildings' external and internal walls, and contents on flow propagation. To take into account these effects, flow into and within buildings should be limited. To achieve this the caFloodPro application allows for the roughness, infiltration (water loss to the surface), 
and rain to be tailored for each cell, or groups of cells. In this case, the desired effect of increased building blockage is achieved by increasing the Manning's roughness from 0.015 to 0.1 to slow down the flow within buildings areas.

To account for the capacity of the sewer system to remove water from the urban surfaces, and the ability of green areas to absorb water, infiltrations rates are set for these areas and shown in Table 1. Although most of the sewer pipes in Torbay were designed to cope with 1 in 30 year return period pluvial event, the current inlets and gullies along the roads do not provide equivalent capacity such that the road drainage is reduced to 1 in 5 year return period event. Additionally a rainfall reduction of $12 \mathrm{~mm} / \mathrm{hr}$ to green areas (cells with natural surface) is implemented.

Table 1: Infiltration/Water loss rates per surface type

\begin{tabular}{lc}
\hline Area type & Infiltration $(\mathrm{mm} / \mathrm{hr})$ \\
\hline Green (any other) & $12+$ (rainfall reduction of $12 \mathrm{~mm} / \mathrm{hr}$ for pluvial cases) \\
Roads Tracks And Paths & 19 \\
Buildings & 28 \\
\hline
\end{tabular}

Two different sizes of the modelling domain were used in the analysis. Firstly a smaller domain was created, limited to just the coastal flood extent, by deliberating the areas lower than $30 \mathrm{~m}$, allowing enough buffers for coastal floods to propagate. For the pluvial and combine cases, a larger area is required to simulate the collection of runoff from the local catchment. This was done through terrain analysis to obtain the catchment boundaries.

\subsection{Overtopping conditions}

The overtopping discharge along the sea defences were produced by the AMAZON model $(\mathrm{Hu}$, 2000) (Ltd, 2017), which simulates the random waves travelling as bores. The discharges for the current and the future climate change scenarios of 1 in 200 year return period event were used as inputs to the CADDIES model as the boundary condition for the cells along the coastal defences. The overtopping rates follow the 12-hour tidal cycle with a total duration of 4 days. The flow rates for the 1 in 200 year storm event, with 2100 projection of climate change are shown in Figure 2Error! Reference source $\mathbf{n}$ ot found..
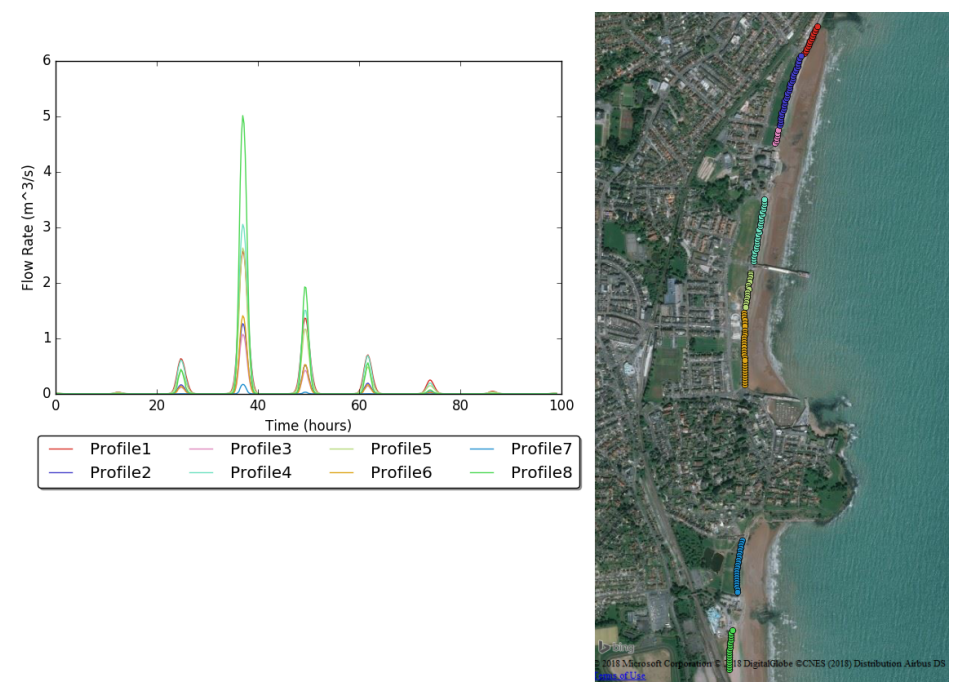

Figure 2: The discharge profiles for 1 in 200 year overtopping event (left) for various coastal sections (right) 


\subsection{Pluvial conditions}

The pluvial flooding analysis adopted a design rainfall (spatial-uniformly distributed across the terrain) for the first hour of these simulations, while a further 3 hours of simulation time is used to allow the flow to propagate through the catchment. The rainfall values for events with different return periods were obtained from the Flood Estimation Handbook (Hydrology, 2013) for each location. These rates were scaled up based on the EA's guidance (Evironment Agency, 2016) to account for future climate change scenarios.

\subsection{Combined pluvial and overtopping conditions}

Considering the chance that both extreme pluvial and overtopping conditions occurring at the same time is low, the combination of moderate pluvial and overtopping conditions were modelled as a plausible situation. A 1 hour design rainfall with 1 in 50 year return period was aligned with the largest peak of the inflow for 1 in 50 year overtopping event at the $36^{\text {th }}$ hour of the simulation. The scenario was applied to analyse the climate change impact for a 50 year projection, as well as to investigate the effectiveness of a possible adaption scenario with an extra sea defence being built.

\section{Results}

Figure 3 shows a 1 in 100 year pluvial event (left) and a 1 in 200 year coastal overtopping event (right), for current climate conditions. Clearly in Figure 3 large populated area are under risk from extreme events, with the majority of risk to the town centre coming from the coastal events. The overtopping has a wider spread flood extent along coastal area while the pluvial flooding are scatter and following the road network. Given 50 years of climate change, Figure 4 shows a 1 in 100 year pluvial (left) and a 1 in 200 year (centre), risk are only set in increase. The coastal flooding in the current scenario (Figure 3) are largely bounded by the railway line and station, however with the increased rail fail and/or overtopping for 50 years of climate change, the railway line and station are completely overwhelmed.
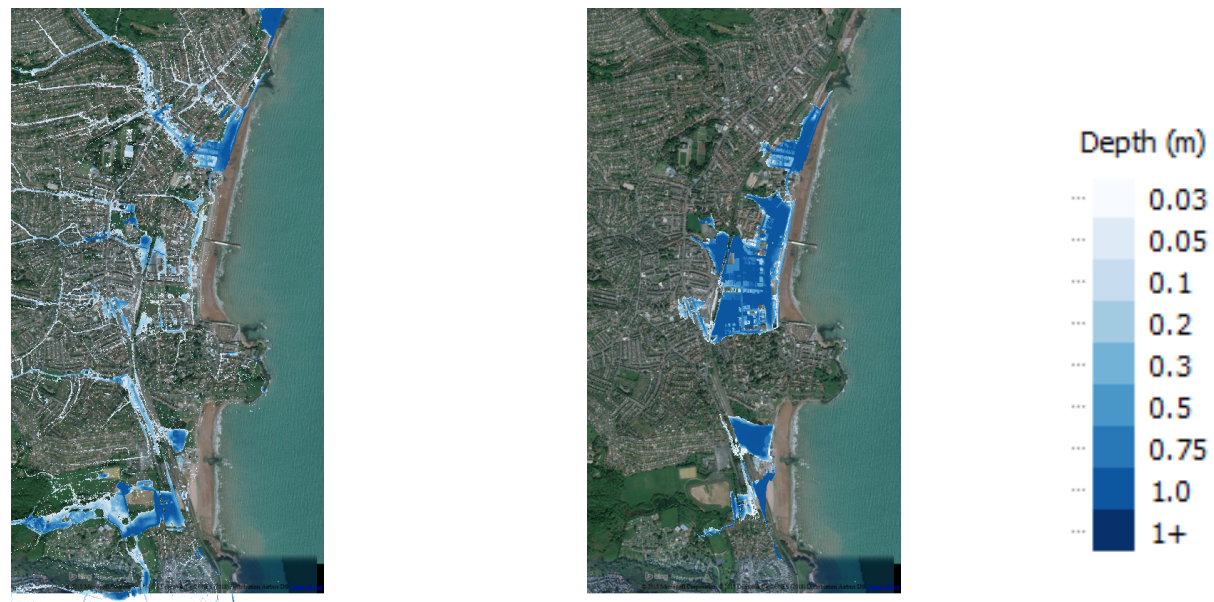

Figure 3: Flood extents of 1 in 100 year return period pluvial event (left) and 1 in 200 year return period overtopping event (right) for the present scenario 
Considering the likelihood for both extreme events (i.e. 1 in 100 year pluvial and 1 in 200 year coastal overtopping) occurring at the same time is rare (Svensson \& Jones, 2005), a moderate combination of both situations was considered to represent the joint extreme event (i.e. 1 in 50 year pluvial and 1 in 50 year coastal overtopping at the same time). The modelled flood extent is shown in Figure 4 (right).

It is clear in Figure 3 and Figure 4 that the coastal overtopping causes the largest risk to a very concentrated area, and therefore an adaptation plan has been developed to make improvements to the sea wall defences. Shown in Figure 5, are the resulting flood depths for a 1 in 200 year coastal overtopping event, given 50 years of climate change, but with the planned improvements to the sea wall drastically reducing the amount of flow, and clearly protecting Paignton from the majority of flooding.


Figure 4: Flood extents of 1 in 200 year return period overtopping event (left) and 1 in 100 year return period pluvial event (centre), and combined 1 in 50 year pluvial and coastal overtopping event (right), for the 50 years of climate change scenario

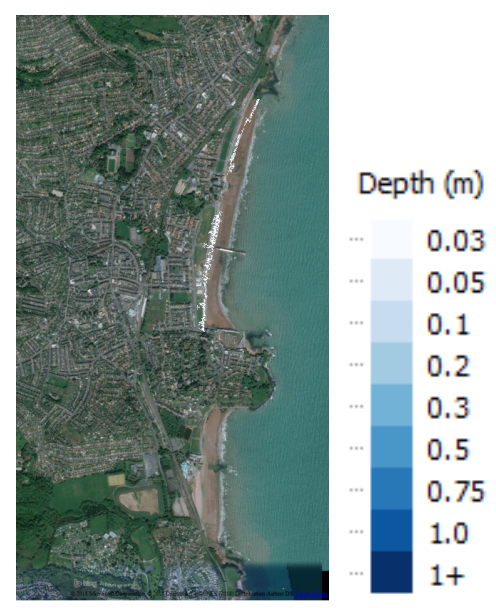

Figure 5: Flood extents of 1 in 200 year coastal overtopping event with 50 years of climate change, and adaptations made the sea wall defences 


\section{Analysis}

To assess the cascading effect of flood impact to CIs, we have adopted the EU-CIRCLE framework (Sfetsos, et al., 2017) (Chen, et al., 2018) in the study. The EU-CIRCLE project considers not only the direct flood damage costs based on flood hazards (e.g. depth), but also the cascaded costs from damage to other types of CI and to properties in the area. For example, if flood damages CI assets such as electrical substations, other properties that are not directly affected by the flooding may still lose power due to the failure of substations. Therefore, CIs such as sewer pumping stations, electricity sub-station, and telecom exchanges will affect a much larger area beyond their locations when they are flooded beyond a certain threshold depth.

The flood information obtained from CADDIES modelling were overlapped with the building layouts, together with the building use information and the depth damage relationships from the MultiColoured-Manual (Penning-Rowsell, et al., 2005) to evaluate the direct flood damage of each property. For CIs, the first level of cascading effect was evaluated using the algorithm shown in Figure 6. The interdependencies among CIs and other properties were further analysed such that the cascading effects can be assessed using the EU-CIRCLE framework through a looped analysis (Chen, et al., 2018).

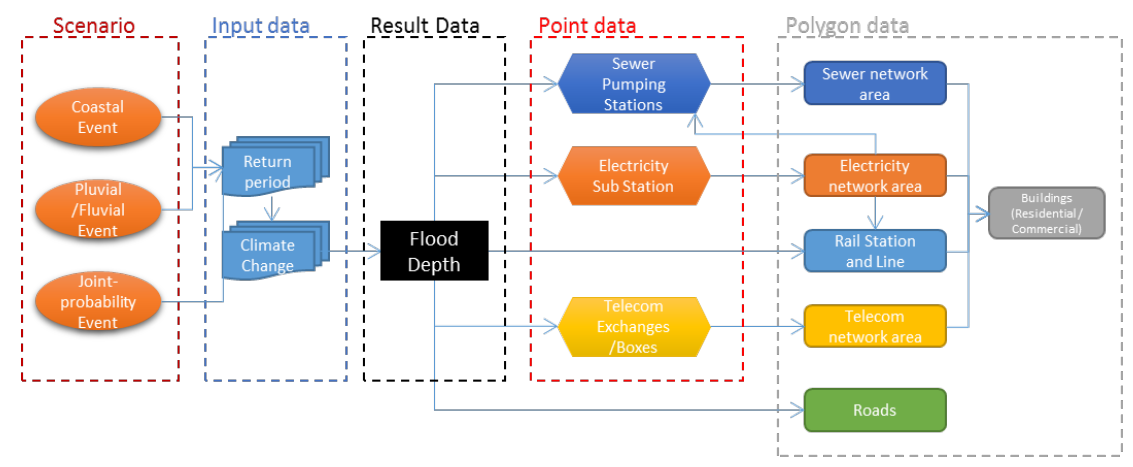

Figure 6: EU-CIRCLE methodology for assessing flood impact on CIs

To demonstrate the modelling results in a more user-friendly way that improves risk communication, we exported the flood depth data to Google Earth Pro allowing stakeholders to explore the study area using the interactive 3D mapping tool. The approach only requires a simple public available software that is easy to operate. Users do not need to install complicated GIS software or purchase the software licence. The application also clearly present the relationship between flood hazards and buildings, as shown in Figure 7, that stakeholders can visualise and better under the threats of flood hazards.

However, the current application can only display static flood information (i.e. maximum flood depth) that cannot demonstrate how flood propagates within the city during an event. It also have limited ability to highlight the level of damage and the impact of cascading effects due to CI failures. Therefore, an advance visualisation tool has been further developed using Unity3d Game engine to create a 3D animated visualisation of flood events (Khoury, et al., 2018). 


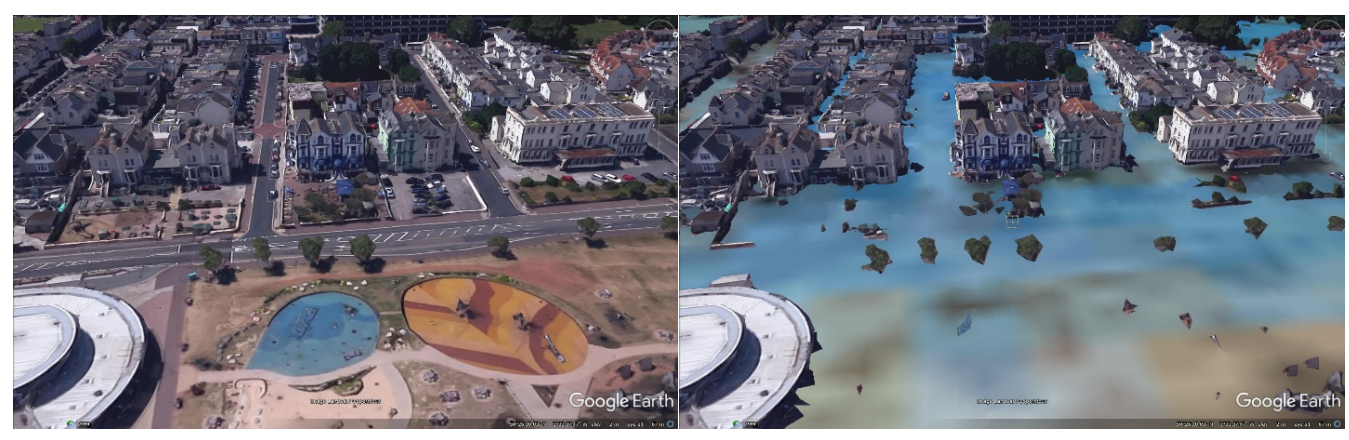

Figure 7: Google Earth Pro visualisation for comparing scenarios without (left) and with (right) flooding

\section{Conclusions}

In the paper, we presented an innovative approach providing scientific evidence, so as to understand better how future climate regimes might affect the normal operation of interconnected CI in urban areas and how to assess the effectiveness of adaptation measures. The methodology was applied to analyse the flood impacts to Torbay due to pluvial, coastal overtopping events and their combinations under the present and future climate scenarios. Both the direct flood damage and the cascading effects due to CI failures were evaluated using and flood hazards information, building characteristics, depth-damage relationship and the interdependencies among CIs and properties. By combining computational modelling with advanced 3D visualisation techniques, we also developed an effective tool for communicating with stakeholders during decision-making process. The application can help local stakeholders and operators in the co-design of the approach, the assessment and the evaluation of adaptation measures.

\section{Acknowledgments}

The work presented in this paper was partially funded by the ongoing EC H2020 EU-CIRCLE (GA 653824) and the FP7 PEARL (Preparing for Extreme And Rare events in coastaL regions, GA 603663) projects. The development of CADDIES model was funded by the UK Engineering and Physical Sciences Research Council, grant EP/H015736/1 (Simplified Dual-Drainage Modelling for Flood Risk Assessment in Urban Areas). The authors would also thank to the Environment Agency, Ordnance Survey (GB), and Torbay Council for the provision of data.

\section{References}

Chen, A. S., Khoury, M., Vamvakeridou-Lyroudia, L., Stewart, D., Wood, M., Savic, D., \& Djordjevic, S. (2018). 3D visualisation tool for improving the resilience to urban and coastal flooding in Torbay, UK. Proceedia Engineering, 212, 809-815.

Evironment Agency, U. (2016). Flood risk assessments: climate change allowances. Retrieved from https://www.gov.uk/guidance/flood-risk-assessments-climate-change-allowances

Guidolin, M., Chen, A. S., Ghimire, B., Keedwell, E. C., Djordjević, S., \& Savić, D. (2016). A weighted cellular automata 2D inundation model for rapid flood analysis. Evironmental Modelling and Software, 84, 378-394. Retrieved from https://doi.org/10.1016/j.envsoft.2016.07.008 
Guidolin, M., Duncan, A., Ghimire, B., Gibson, M. J., Keedwell, E. C., Chen, A. S., .. Savić, D. A. (2012). CADDIES: a new framework for rapid development of parallel cellular automata algorithms for flood simulations. Hamburg, Germany. Retrieved from https://ore.exeter.ac.uk/repository/handle/10036/3742

Guidolin, M., Duncan, A., Keedwell, E. C., Chen, A. S., Djordjević, S., \& Savić, D. A. (2011). Design of a graphical framework for simple prototyping of pluvial flooding cellular automata algorithms. Urban Water Management - Chall. Oppor. Exeter, UK.

Hu, K. (2000). High-Resolution Finite Volume Methods for Hydraulic Flow Modelling. Manchester, UK: Centre for Mathematical Modelling and Flow Analysis, Manchester metropolitan.

Hydrology, C. f. (2013). Flood Estimation Handbook. Wallingford, UK. Retrieved from http://www.ceh.ac.uk/services/flood-estimation-handbook

Khoury, M., Chen, A. S., Gibson, M. J., Vamvakeridou-Lyroudia, L., Steward, D., Wood, M., . . . Djordjević, S. (2018). A serious game to explore different flooding scenarios and their respective effects on infrastructuers. Palermo, Italy.

Ltd, H. U. (2017). Torbay coastal Defences - Climate Change Adaptation - Quick Winds Study.

Penning-Rowsell, E., Johnson, C., Tunstall, S., Tapsell, S., Morris, J., Chatteron, J., \& Green, C. (2005). The benefits of flood and coastal risk management: A handbook of assessment techniques. London, UK: Flood Hazard Research Centre, Middlesex University.

Priestnall, G., Jaafar, J., \& Duncan, A. (2000). Extracting urban features from LiDAR digital surface models. Computer, Environment and Urban Systems, 24(2), 65-78.

Sfetsos, A., Vamvakeridou-Lyroudia, L., Chen, A. S., Khoury, M., Savic, D., Djordjevic, S., . . . Karavokrros, G. (2017). Enhancing the resilience of interconnected critical infrastructures to climate hazards. 15th Internation conference on Environmental Science and technology. Rhodes, Greece.

Svensson, C., \& Jones, D. A. (2005). Joint Probability: Dependence between extreme sea surge, river flow and precipitation: A study in South and West Britain. London: Defra Flood management division/Environment Agency, UK. Retrieved from http://evidence.environmentagency.gov.uk/FCERM/Libraries/FCERM_Project_Documents/FD2308_3430_TRP_pdf.sfl b.ashx

UK, E. A. (2013). What is the updated Flood Map for Surface Water? Evironment Agency, Bristol, UK. 